Lektorált tanulmányok

\title{
A hazai kisvasutak forgalmának turisztikai potenciál alapú vizsgálata
}

\author{
Szerzők: Princz-Jakovics Tibor ${ }^{1}$ - Vasvári Gergely²
}

A turisztikai attrakciók közül a kisvasutak jelentôsége erôsödött az elmúlt években, melynek megfelelően a turisztikai tényezők hatása kiemelten kezelendő a kínálati oldalon. Tekintettel az egyes kisvasúti vonalak elkülönülő, szigetüzem jellegére, a várható utasforgalmi jelenségeket (például forgalmi igény nagysága) az eszközválasztás korridor-modelljével írtuk le. E modell alkalmazása esetén az adott vonalon tapasztalható utazási szokások és várható trendek a környezó nagyobb (városi, regionális stb.) hálózatrészek figyelembevétele nélkül becsülhetőek meg.

A turisztikai és vegyes személyforgalmi igény - fejlesztések hatására történô - megváltozásának becslése több szempont felhasználásával valósult meg. A forgalmi kategóriákra differenciált csoport (cluster) elemzést alkalmaztunk a diverzitás melletti kis mintaszám miatt.

A turisztikai forgalmat a kisvasút, illetve környezetének fejlesztésével lehet javitani, amiben fontos szerepet kap nemcsak a vonzó elemek megléte, hanem azok értéke is. A hivatás és turisztikai funkció párhuzamos fenntartása a potenciális felhasználók számát növelheti egy-egy kisvasút esetén, így ezekre jó gyakorlatokat kerestünk (például hibrid menetrend kialakításával).

Kulcsszavak: kisvasutak, forgalmi igény, turisztikai potenciál.

\section{Bevezetés}

A turisztikai attrakciók közül a kisvasutak jelentősége erősödött az elmúlt években, melynek megfelelóen a turisztikai tényezók hatása kiemelten kezelendő a kínálati oldalon. A kisvasutak jelenlegi adottságainak, illetve jövőbeni fejlesztési lehetőségeinek feltárására Országos Kisvasúti Koncepció (OKK) készült 2015 végén (TRANSINVEST 2015), amely egységes módszertani megközelítéssel vizsgálta a kisvasutak speciális és színes témakörét. Ez azért is hiánypótló volt, mivel a STRATÉGIA KONZORCIUM (2013) által kidolgozott Nemzeti Közlekedési Stratégia és az annak részét képező Országos Vasútfejlesztési Koncepció nem érintette részleteiben a kisvasutak témakörét. Az OKK részeként a kisvasutak forgalmi jellemzőit értékeltük, ez a cikk elsődlegesen ezeket az eredményeket jeleníti meg. Átfogó, koncepcionális szintú vizsgálatként az OKK megállapításai, adatsorai továbbra is érvényesnek tekinthetôek.

\footnotetext{
1 egyetemi adjunktus, Budapesti Müszakiés Gazdaságtudományi Egyetem, tprincz@eik.bme.hu

2 egyetemi adjunktus, Budapesti Müszaki és Gazdaságtudományi Egyetem, vasvari.gergely@epito.bme.hu
}

A téma aktualitását a közelmúltban elkezdődött felújítások és a kormányzati oldalról már bejelentett további beruházások jelzik. Az elérhetô területfejlesztési pályázati források lehetóséget nyújtanak a finanszírozási háttér megteremtésére, amelynek köszönhetően az egyes kisvasutak a tulajdonosi viszony, illetve az üzemeltető jogi státusza szerint tudnak fejlesztési és üzemeltetési forrásokra pályázni.

Jelen áttekintés a 29 meglévő erdei-, gazdasági-, múzeum- és MÁV kisvasúttal foglalkozik, amelyek a közelmúltig, vagy jelenleg, esetleg a közeljövőben tervezetten végeztek vagy végeznek személyszállítást, azonban a bányavasutakra és a téglagyári vasutakra nem terjed ki. A személyszállítást végző kisvasutak térbeli eloszlását külön jelenítettük meg: az országon belüli elhelyezkedésüket az 1. ábra mutatja.

A vizsgált kisvasutak jellemzően a MÁV Zrt., állami erdészetek, önkormányzatok vagy magántulajdonú gazdálkodó szervezetek tulajdonában vannak. Vágányhálózatuk hossza összesen 510 km, melyból jelenleg 224 km-en van múködő üzem. Nyomtávjuk szinte kizárólag 760 mm. A gördülő állományt 122 mozdony, 239 személykocsi és 329 teherkocsi alkotja. A kisvasutak infrastruktúrájáról és gördülő állományáról további múszaki öszszefoglalást az F\&B CONSULTING Bt. - XELLUM 
Lektorált tanulmányok

Kft. (2008) tanulmánya, KÖLLER 2016-os ismertető cikk-sorozata, valamint a CSIBA és szerzőtársai (2007) által készített jármúalbum tartalmaz.

Ahogy a fent említett tulajdoni viszonyok sugallják, a jelenleg személyforgalmat is bonyolító kisvasutak kialakulása ugyancsak sokszínú. Legtöbb esetben bányavasutak, erdészeti vasutak teherforgalmi pályáinak bővítésével, illetve átalakításával jöttek létre a mai vonalak. Ezért az egyes vasutak elhelyezkedéséból adódóan sok esetben - az áruszállításon túl, a személyforgalmat tekintve - a turisztikai funkció a meghatározó, de több esetben a hivatásforgalmi funkció is megjelenik. Ezért érdemes részletesebben foglalkozni a turisztikai jellemzőkkel. Az alábbiakban részletezett elemzési módszer elsô lépésként utasforgalmi kategóriákra bontja a teljes vizsgálati halmazt, azok nagyságrendi besorolása alapján. E kategorizálást az összes rendelkezésre álló utasforgalmi adat áttekintése után, a csoportra jellemző értékek meghatározásával végeztük. További vizsgálatunkban a nemzetgazdasági mutatók utasforgalmi befolyását elemeztük, melyet már az imént említett kategóriákra bontottunk, így a vonalanként viszonylag kis számú adatból összevont statisztikát képezve becsültük meg a várható tendenciákat. Cikkünk második felében felsoroljuk azokat a módszertani megfontolásokat, melyekkel részletesebb vizsgálatok végezhetők, és amelyek az OKK készítésének keretein belül végrehajtásra kerültek bizonyos kiemelt vasútvonalaknál.

\section{A kisvasutak keresleti oldalának áttekintése}

\subsection{JELENLEGI FORGALOM ÉS KATEGORIZÁLÁS}

Tekintettel az egyes kisvasúti vonalak szeparált, vonalas jellegére, a várható utasforgalmi jelenségek (forgalmi igény mennyisége, eszközválasztás) szúkített, úgynevezett korridor-modellel kerültek leírásra. E modell alkalmazása esetén kizárólag az adott vonalon tapasztalható utazási szokások és várható trendek adják a kutatás alapját, a környezô nagyobb (városi, regionális stb.) hálózatrészek figyelembe vétele nélkül. Érdemes megjegyezni, hogy bár maguk a (kis)vasút vonalak valóban elkülönített egységek, a párhuzamos közlekedési rendszereken (autóbusz, személygépkocsi) megjelenő utazások korántsem az adott vonalak két végpontja közé korlátozódnak, kiterjedésük annál nagyobb. Ezért a párhuzamos rendszereken jelen-

\section{Személyszállítást végzố kisvasutak elhelyezkedése}

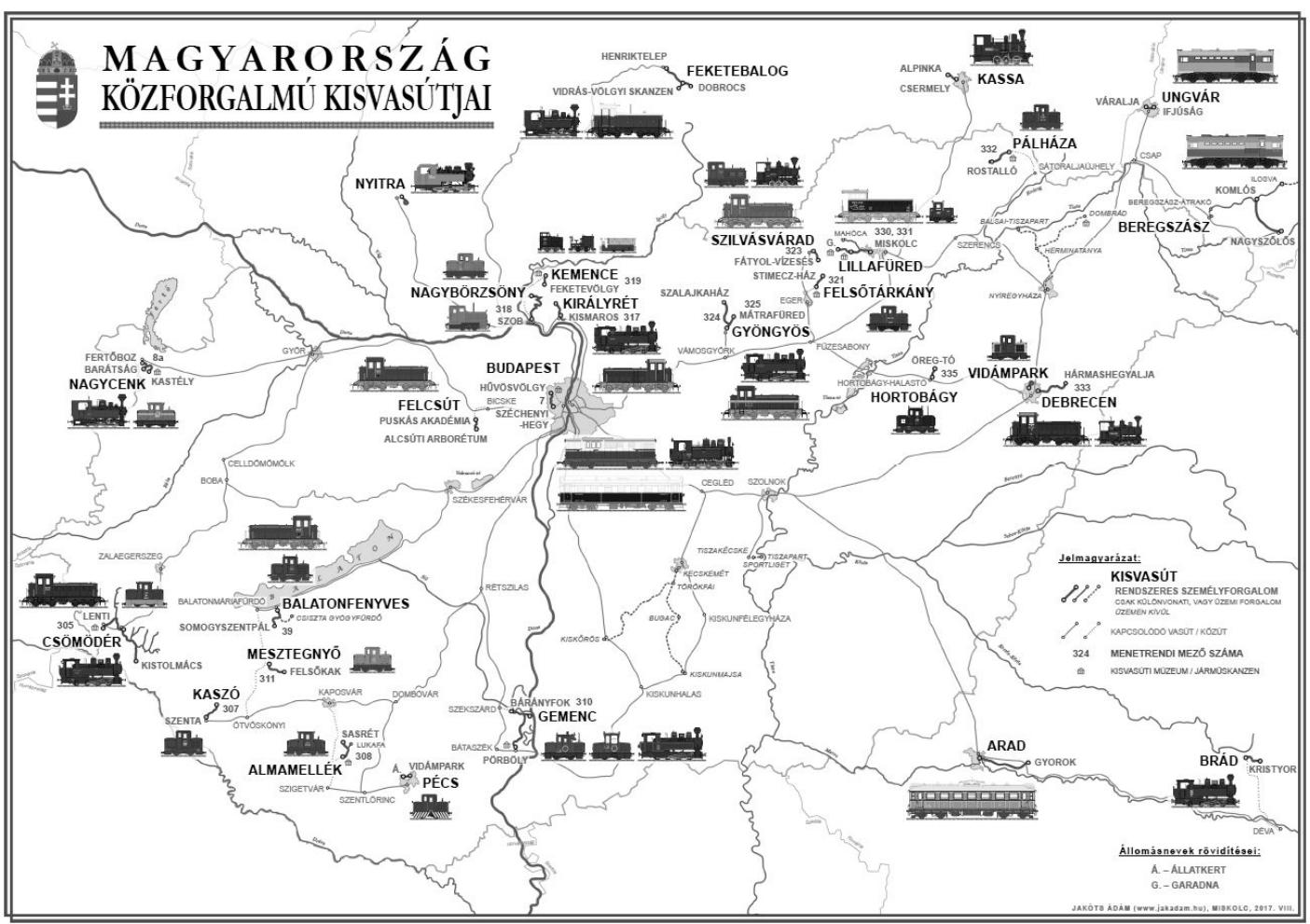

Forrás: Jakóts Á. szerző engedélyével 
lévő utasszámok, potenciális kisvasút használók megítélése célzott felméréseken alapul, melyek hiányában körültekintő becsléseket szükséges végezni. A közlekedés gazdaságban betöltött szerepét a forgalmi teljesítmények és a személyszállítási piac jellemzői jelentős mértékben meghatározzák (JÁSZBERÉNYI - PÁLFALVI 2006), ezért a helyzetfelméréshez, illetve a turisztikai potenciál feltárásához a keresleti oldal vizsgálata szükséges.

Áttekintésünk alapját az OKK készítését segítô, az üzemeltetôk által az infrastruktúrára, a jármúállományra és a forgalmi jellemzőkre kitöltött kérdőívek, valamint a nem üzemelő Nyírvidéki és

Kisvasutak 2015. évi utasforgalmi adatai

2. ábra (utasfó/év)

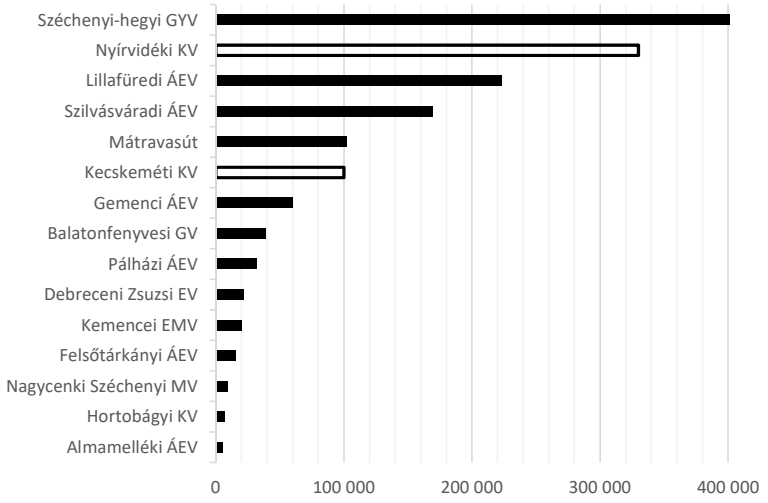

Forrás: saját szerkesztés a Kecskeméti Kisvasút esetén becsült utasforgalmi értékek jelentik, melyek összefoglalását a 2. ábra mutatja. A késóbbi kategorizálás elvégzése érdekében a diagram forgalomnagyság szerint sorba rendezve ábrázolja az egyes kisvasutakat.

$\mathrm{Az}$ utasforgalmi értékek széles skálája miatt csoportosításra van szükség, mellyel a turisztikai és vegyes személyforgalom nagysága alapján jól elkülönülő nagyságrendi sávokra oszthatók a vizsgált vasútvonalak:

• alacsony forgalmú: 1.000-10.000 fő/év (Almamelléki ÁEV, Hortobágyi ÁEV, Nagycenki Széchenyi MV),

- közepes forgalmú: 10.000-100.000 fő/év (Felsőtárkányi ÁEV, Kemencei EMV, Debreceni Zsuzsi EV, Pálházi ÁEV Balatonfenyvesi GV, Gemenci ÁEV),

- nagy forgalmú: 100.000-1.000.000 fő/év (Kecskeméti KV, Mátravasút, Szilvásváradi ÁEV, Lillafüredi ÁEV, Nyírvidéki KV, Széchenyihegyi GYV).

\subsection{A TURISZTIKAI FORGALOM ÖSSZEFÜGGÉSE A NEMZETGAZDASÁGI MUTATÓKKAL}

A turisztikai forgalmi igény - fejlesztések hatására történő - megváltozásának becslése több szempont felhasználásával valósul meg. A vasútvonalak üzemeltetőivel végzett kérdőíves interjú utasforgalmi adatai összefüggésbe hozhatók a nemzetgazdaság kiemelt mutatóival a felmérést megelőzó évhez (2014) képest vett relatív mértékben (3. ábra).

3. ábra

Turisztikai célú utasforgalom időbeli alakulása az országos gazdasági mutatókkal összevetve
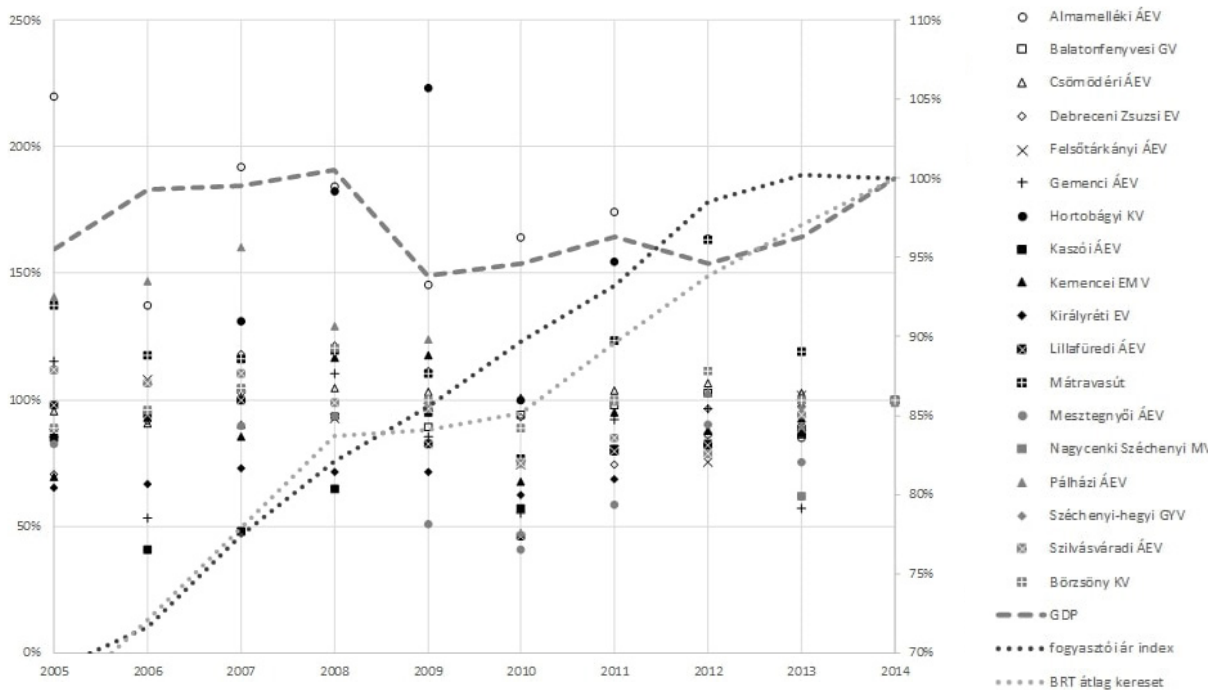

Forrás: saját szerkesztés a KSH és az utasforgalmi kérdőíves felmérés adatai alapján

Megjegyzés: a bal oldali tengelyen az utasforgalom nagysága (2014. év = 100\%), a jobb oldali tengelyen a gazdasági mutatószámok (2014. év = 100\%) értékei láthatók. 
Lektorált tanulmányok

A diverzitás mellett tapasztalható kis mintaszám miatt differenciált csoport (cluster) elemzést célszerú alkalmazni, melynek alapját az előzóekben megállapított személyforgalmi kategóriák adják.

A kisvasutak utasforgalmának időbeli változását szemlélve megállapítható, hogy a legtöbb esetben a 2008-as gazdasági válság csak később, a 2010-es évben vezetett drasztikus csökkenéshez, melyet sok esetben egy újabb, de kisebb mértékú visszaesés követett 2013-ban. Ennek okán a továbbiakban bemutatott előrejelzések a 2011-es évvel kezdődően veszik figyelembe az utasforgalmi adatokat. Az utasszám-változás nemzetgazdasági mutatóktól való függésének vizsgálata egyértelmú pozitív korrelációt mutat.

\subsection{UTASFORGALOM ELŐREJELZÉSE}

Rövidtávon, a nemzetgazdasági mutatók és fejlesztések pontos ismerete vagy becslése nélkül - statikus körülmények között - a megelőző években

\section{Rövidtávú személyforgalmi tendencia az alkalmazott elemzési kategóriákban a 2011-2014 idôszak adatai alapján}

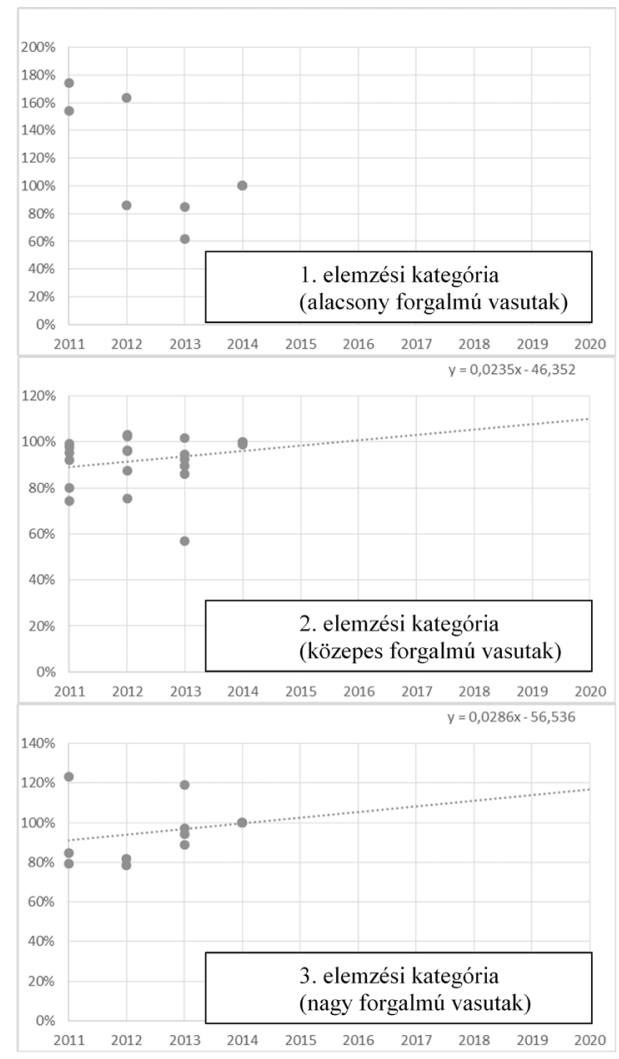

Forrás: saját szerkesztés tapasztalható enyhe növekvő tendencia vehetô iránymutatónak a turisztikai célú utasforgalom becsléséhez. Ahogy azt korábban említettük, a becslésekhez a 2011-es évvel kezdôdően vettük figyelembe az utasforgalmi adatokat. Az elemzési csoportok (cluster) egyedi tendenciái az alábbiakban láthatóak (4. ábra).

Megjegyzendó, hogy az 1. elemzési kategória esetén a minta igen kicsinek és nagy szórásúnak bizonyult az utasforgalmi trend megbízható becsléséhez, ezért e kisvasutaknál is a 2. elemzési kategória eredményei tekintendők mértékadónak.

A vizsgálat eredményeként az előrejelzett átlagos éves utasforgalmi változás a 2018-2020 közötti idôszakra, a 2015. évihez viszonyítva, sorrendben a következó: 7,0\%; 9,4\% és 11,7\% (1. és 2. elemzési kategória), illetve 7,8\%, 10,5\% és 13,1\% (3. elemzési kategória). A várható forgalom-változás volumene tehát dinamikus utasszám növekedést mutat, amelyre a releváns kapcsolatrendszer feltárásának segítségével további turisztikai fejlesztéseket lehet alapozni.

\section{A kisvasutak turisztikai kapcsolatrendszere}

Mivel az egyes vonalak turisztikai értelemben vett vonzósága erősen függ a közelükben található látnivalóktól, programlehetőségektől, az egyes fejlesztések turistaforgalom vonzó hatását potenciál alapú vizsgálattal írjuk le. A vasútvonalak üzemeltetôivel végzett kérdőíves interjú az adott helyszínen jelenlévő, turisztikailag vonzó úti célokat is összesítette. Ezen attraktív elemekhez - azok turisztikai értéke szerint rendelt - súlyszámokkal képezhető a teljes potenciál, ami jelzi a létesítmények vonzóságának a megjelenó turisták létszámára, az utasforgalom nagyságára gyakorolt hatását.

$\mathrm{Az}$ új fejlesztések a már elemzett összetevők alapján képzett súlyokat kapják, így az újonnan kialakult potenciál hatása becsülhetó a turisztikai forgalomra nézve. Az új - a felmérésben nem szereplő - tényező́k hatása ez esetben is becslésből származtatható. A kérdőíves felmérések eredményeit az 5. ábra összesíti. A „kisvasút preferencia” jelzéssel ellátott elemek esetén az utazásra jogosító igazolás (vonatjegy) felmutatásával különbözố kedvezmények érvényesíthetőek.

Megvizsgálva az idegenforgalmi létesítményeket, a következő megállapítások tehetők:

- Néhány vonal kivételével, a kisvasúttal megközelíthető látványosságok, programok, felkínált szolgáltatások elérése kedvező, azok majdnem mindegyike a megállóhelyen vagy annak közvetlen környezetében található. Ez 
Idegenforgalmi létesítmények a kisvasutak vonzáskörzetében

Forrás: saját szerkesztés

azonban nem függ össze az adott vonal utasforgalmával, mely jelezheti a rendelkezésre álló potenciál kiaknázatlanságát.

- A legtöbb kisvasúttal elérhetó turisztikai célpont kerékpárral is megközelíthetô. E tény ismeretében és a jelen körülmények közt erôs támogatást élvezó ökoturisztikai fejlesztések tudatában kijelenthető, hogy a kerékpárszállítás lehetôvé tétele - az erre számot tartó vonalak esetén - fontos, valamint az ez irányú fejlesztési szándék alátámasztható, ezért a szükséges támogatási források feltehetóen megszerezhetóek. Figyelembe véve a nemzetközi példákat, az ökoturizmus részét képezheti a tóparti (például Balatonfenyvesi Gazdasági Vasút), illetve a nemzeti parkokhoz kapcsolódó (például Öreg-tavi Kisvasút Hortobágyon) szolgáltatások bővitése (LUNDBERG - FREDMAN 2012, EUROPARC FEDERATION 2010). További segítséget nyújthat az elért eredmények értékeléséhez, illetve a fejlesztések tervezéséhez a fenntarthatósági elemzések, teljesítmény indikátorok alkalmazása (POMUCZ - CSETE 2015, CASTELLINI SALA 2010).
- Kisvasúttal szinergiában lévő turisztikai célpontok az értékelhetó válaszadók majdnem felénél vannak jelen. Ezen esetek legtöbbjében a kisvasúttal történő összefonódás kiterjedt, nemcsak egy-egy célpontnál (például szálláshely, étterem, fürdóhely) van jelen, hanem azok legalább harmadánál-felénél, tehát - ahol az adott kisvasút vezetôsége, üzemeltetói a szükséges lépéseket megtették - az együttmúködés széles körúen megjelent. Érdemes megemlíteni, hogy e csoportban találhatók kifejezetten nagy forgalmú (Lillafüredi, Szilvásváradi) és alacsony forgalmú (Felsőtárkányi, Nagycenki) kisvasutak is.

- Horizontálisan a könnyen befolyásolható, telepíthető elemek közül a kerékpár bérlési lehetôség, nehezebben kezelhetó elemek közül pedig az állatkert, gyógyfürdő, horgásztó túnik ki nehezen befolyásolható elérhetőségével (10 percnél több gyalogtúrával) - leszámítva természetesen azon eseteket, ahol nincsenek jelen e szolgáltatások. A játszótér, sportolási lehetóség, rekreációs lehetőség azonban a legtöbb esetben könnyen, gyorsan elérhető, jó alapot teremtve a már említett ökoturizmus 
irányába történő fejlesztéseknek. Mivel az étkezési lehetőségek általában könnyen elérhetőek, a hosszabb, akár egész napos programok tervezése, ajánlása is elképzelhetó az utazók számára, mely elősegíti bizonyos vasútvonalak kedvező tematizálását (errôl részletesebben írunk az 5. fejezetben).

\section{Eszközválasztást befolyásoló hatások, modellezési lehetóségek}

\subsection{FUNKCIONÁLIS ÖSSZEFÜGGÉSEK}

A turisztikai célú személyforgalom eszközválasztására ható elemeket (6. ábra) szolgáltatási színvonallal jellemezzük. E jellemző más szemszögből közelíti meg az utazás, helyváltoztatás érdekében tett erőfeszítést, mint a jellemzóen hivatásforgalom esetén fontos hasznosság. A színvonal kényelem-központú, jellemzően pihenni, kikapcsolódni vágyók döntését befolyásolja. A hasznosság ellenben a hatékonyság alapú döntések esetén fontos, mely a munkába járó utazók (például elővárosi közlekedés) mindennapokra vonatkozó, a turisztikainál jelentősen hoszszabb távú döntéseit befolyásolja. A két jellemző az egyes személyszállítási célterületek módválasztásának mérlegelése esetén nyeri el jelentôségét. eszközválasztás

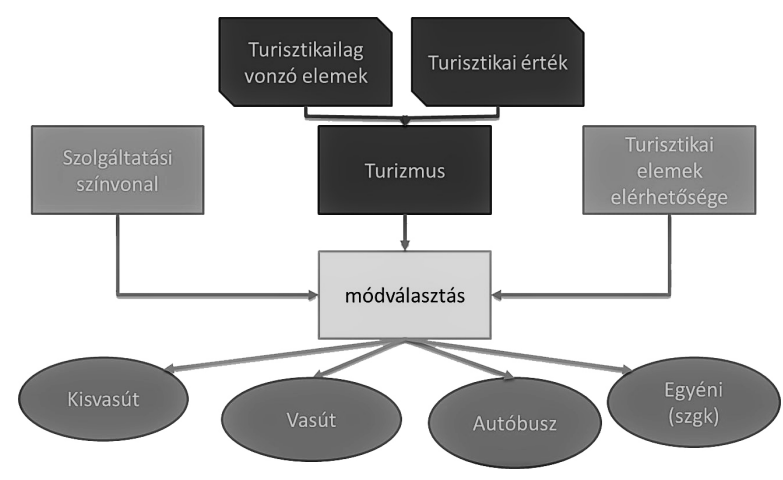

Forrás: saját szerkesztés

A turisztikai forgalom megjelenését esetünkben már a forgalom keletkezésének oldaláról vizsgálni kell, melyet a kisvasút, illetve környezete fejlesztésével befolyásolni - fellendíteni - is lehet. Ebben fontos szerepet kap nemcsak a vonzó elemek megléte, hanem azok értéke (pihenéssel eltölthető idó hossza, minősége) is. Ugyanakkor az elérhetőség, megközelíthetőség jelentôsen eltolhatja a módválasztás arányát a kisvasút rovására.
A hivatás és turisztikai funkció párhuzamos fenntartása a potenciális felhasználók számát növelheti egy-egy kisvasút esetén. Azon kisvasúti üzemek, melyek földrajzi helyzetükből kifolyólag alkalmasak lehetnek hivatásforgalomra, egyúttal alkalmasak turisztikai forgalomra is. A két eltérố igény kiszolgálása történhet hibrid menetrend kialakításával, mely kizárólagos turisztikai forgalom esetén is megfontolandó opció. E menetrend párhuzamosan tartalmazza a gyors és lassú járatok üzemeltetését az adott vonalon. A gyors járatok kis utaskapacitással (például egy motorkocsi), nagyobb sebességgel, esetlegesen bizonyos állomások kihagyásával szállítanák a célirányos utazókat, míg a lassú járatok nagyobb kapacitással (két-három motorkocsi), a helyi látnivalók befogadására alkalmas sebességgel végeznének személyszállítást. Az ilyen fajta vegyes menetrend nemcsak a vegyes (hivatás- és turista) forgalom párhuzamos kiszolgálását tenné lehetôvé, hanem azon turistákat is megnyerheti a kisvasút választására, akik ugyan kíváncsiak a látnivalókra, de csak egy alkalommal, az egyik irányba utazva, mivel fennmaradó szabadidejüket szívesebben töltenék a célterületen (például a természetben), mintsem hogy a visszafele utazásra fordítsák. Ezen utazók jelenleg más közlekedési módot választanak, és kihagyják a kisvasutat utazási láncukból az élmények redundáns volta miatt.

\subsection{ESZKÖZVÁLASZTÁSI MODELLEK}

Egyes kisvasút vonalak esetén nem állt rendelkezésre elegendó információ a párhuzamos közlekedési rendszerekre (autóbusz, illetve egyéni közlekedés) is kiterjedô választási szokásokról. Ezért az utazási kínálat mennyiségi és minóségi változása (rekonstrukció, fejlesztés) esetén elóálló, a közlekedési eszközök közti új megoszlás meghatározására szakirodalmi adatokon alapuló, becsléssel kiegészített növekményes (inkrementális) típusú modellek alkalmazására nyílik lehetőség. Ezek rövid bemutatása és alkalmasságuk értékelése olvasható az alábbiakban, ORTÚZAR és WILLUMSEN (2011) múve alapján.

A többféle parametrizálási lehetóségre módot adó, inkrementális típusú modelleknél az utazási igény megismert - esetünkben becsült - rugalmasságát (elasticity) kihasználva állapítható meg a kialakult szolgáltatási színvonal-változás által bekövetkező forgalmi igény-változás.

$$
E_{i}=\frac{S_{0}}{T_{0}} \cdot \frac{\Delta T}{\Delta S}
$$


Lektorált tanulmányok

- $\mathrm{E}_{\mathrm{i}}=$ az eszközválasztás rugalmassága i közlekedési mód esetén,

- $\mathrm{S}_{0}=$ eredeti szolgáltatási szint,

- $\mathrm{T}_{0}=$ eredeti (utas-) forgalom,

- $\Delta S$ = szolgáltatási szint megváltozása,

- $\Delta \mathrm{T}$ = forgalom megváltozása.

Egyrészt hasznosítható az egyenlet $\frac{S 0}{\mathrm{NS}}$ vagy $\frac{\mathrm{OT}}{\mathrm{T} 0}$ tagja, hiszen ezek a szolgáltatási szint, illetve utazási igény relatív megváltozását adják. Másrészt, ismert $\mathrm{T}_{0}$ forgalmi igény esetén kiszámítható annak abszolút megváltozása is:

$$
\Delta \mathrm{T}=\mathrm{E}_{\mathrm{s}} \cdot \mathrm{T}_{0} \cdot \frac{\mathrm{S}-\mathrm{S}_{0}}{\mathrm{~S}_{0}}
$$

A szolgáltatási színvonal meghatározása, számszerúsítése egyedi kalibrációt igényel, azonban relatív változásának becslése megbízhatóbban elvégezhető. $A$ választás rugalmasságának értékét például nemzetközi vizsgálatok alapján meg lehet becsülni.

\section{A kisvasutak turisztikai hasznosításának fejlesztése}

\subsection{SZOLGÁLTATÁSI IGÉNYFELMÉRÉS}

A forgalmi igény előrejelzések és eszközválasztási modellek alapján könnyebben tervezhetőek a turisztikai fejlesztések. Ismerni kell továbbá, hogy a kisvasutak által nyújtott szolgáltatásokat hogyan értékelik az utasok. Ehhez nyújt segítséget a Digital Consulting által készített tanulmány (VLK CONSULTING - DIGITAL SOLUTIONS 2015) alapját képező kérdőíves felmérés, amely a meglévő szolgáltatásokkal való elégedettség felmérésére, a lehetséges fejlesztésekkel nyújtható új szolgáltatásokra, illetve a vonzáskörzet turisztikai célpontjainak igénybevételi szándékára vonatkozott egy kiválasztott kisvasútra, a debreceni Zsuzsi Erdei Vasútra irányulóan. Értékelték például a járatsûrúséghez kapcsolódó elégedettséget, amely kedvezónek volt tekinthetó, illetve a megkérdezettek többsége egyetértett a jelenlegi nyomvonal meghosszabbításával az elóvárosi közlekedéshez kötődően.

A hasonló igényfelmérések és a szolgáltatásokkal való elégedettség vizsgálata az érintettek körében (beleértve az üzemeltetőket, tulajdonosokat, önkormányzatokat, lakosságot) hozzájárul a körültekintő fejlesztési elképzelések megfogalmazásához, a turisztikai potenciál kihasználásához.

\subsection{TURISZTIKAI FEJLESZTÉSEK}

Az OKK részletes javaslatokat tartalmaz a kisvasutak turisztikai hasznosításának javítására, és a környezetvédelmi szempontok fokozottabb érvényesítésére vonatkozóan. Ezek a javaslatok röviden az alábbiakban foglalhatóak össze.

Idôszakos üzem bövitése a tematikus üzenetekkel: a Lillafüredi ÁÉV Mikulás-vonata jó példa arra, hogyan lehet a vonzerőt és a közlekedési funkciót kombinálni, a tematizáltságot bevezetni, illetve bővíteni, figyelve a partneri kapcsolatokra (például nemzeti park igazgatóságokkal), hiszen a témát leggyakrabban a természeti környezet sajátos jellemzói adják.

A kisvasúti vonalak tematikus úttá alakitása során a tematikus út több elemból, illetve szakaszból áll, amelyeket az útvonal állomásain történó megállással lehet felkeresni vagy megtekinteni. Mindez létrehozható további megállók kialakításával, a megállókban vonzeró-bemutató és tevékenység ajánló információs táblák kihelyezésével; a megállók között alternatív gyalogos és kerékpáros ösvények, illetve fotóösvények és fotópontok kijelölésével, így segítve az élmény megszerzését és elraktározását, valamint a tartózkodási idő növelését.

A fentiekhez kapcsolódóan a körjárati forgalom kialakításával a rövidebb vonalak mentén alakíthatók vagy jelölhetók ki gyalogos és kerékpáros (esetleg sí) útvonalak, amelyek megadják a lehetőséget a látogatóknak arra, hogy szabadon kombinálják az egyes szakaszokat, körbejárják a területet. Ehhez szükséges a vasúti kocsik kerékpár-szállításra való alkalmassá tétele, vagy az üzemeltetók vagy partnereik által kerékpár (esetleg sí) bérlési szolgáltatások kínálatának megteremtése. Körjáratra időszakosan múködő példa a gemenci kisvasút, ahol a Gemenci-erdóben történó vonatozás után a Gemenc-Dunapart állomáson át lehet szállni egy dunai sétahajóra, és azzal visszatérni a kiinduló pontra.

\section{6. Összefoglalás}

Jelen vizsgálat során bemutattuk a turisztikai motivációjú közlekedés, helyváltoztatás kisvasúti környezetének sokféleségét. Forgalmi adatsorok alapján kategorizáltuk, illetve előrevetító elemzéssel összehasonlítottuk az utasszámokat, valamint meghatároztuk a nehezen számszerúsíthető, utasvonzó képességet befolyásoló turisztikai tényezőket az egyes vasútvonal-csoportokra. Javaslatot adtunk továbbá a jövőbeni fejlesztések hatására bekövetkezô közlekedési eszközválasztás alakulásának 
Lektorált tanulmányok

becslésére, figyelembe véve a vizsgált közlekedési rendszer (kisvasút) elszigeteltségét, a környező közlekedési rendszerektől való magas fokú függetlenségét.

A döntéshozók számára a fejlesztési javaslatokat a forgalmi és infrastrukturális jellemzókön alapuló turisztikai potenciál feltérképezésével, kihasználásával, és a kisvasutak egyediségének figyelembevételével célszerú kidolgozni. Ehhez adtunk meg jó gyakorlatokat, lehetséges turisztikai projekt-elemeket.

\section{Felhasznált irodalom}

CASTELLINI, V. - SALA, S. (2010) Sustainable performance index for tourism policy development. Tourism Management. 31(6). pp. 871-880.

CSIBA J. - MALATINSZKY S. - MURÁRIK L. - NÉMETH A. - TÁRCZY T. - VOZÁRY GY.

- ZÁKONYI GY. (2007): Magyar Államvasutak Zrt. jármúalbum. MÁV Zrt. Kommunikációs Igazgatóság, Budapest.

F \& B CONSULTING Bt. - XELLUM Kft. (2008): Magyarországon múködô kisvasutak helyzetének elemzése, fejlesztésük lehetôségei, fenntartható múködésük. Készült az Önkormányzati és Területfejlesztési Minisztérium megbízásából. Budapest.

JÁSZBERÉNYI M. - PÁLFALVI J. (2006): Közlekedés a gazdaságban. AULA, Budapest.

KÖLLER L. (2016): Magyarországi kisvasutak Országos Kisvasúti Koncepció. Sínek Világa. A Magyar Államvasutak Zrt. pálya és hídszakmai folyóirata. 1. pp. 15-21.
LUNDBERG, C. - FREDMAN, P. (2012): Success factors and constraints among nature-based tourism entrepreneurs. Current Issues in Tourism. 15(7). pp. 649-671.

ORTÚZAR, J. D. - WILLUMSEN, L. G. (2011): Modelling Transport. Wiley.

POMUCZ, A. B. - CSETE, M. (2015): Sustainability Assessment of Hungarian Lakeside Tourism Development. Periodica Polytechnica Social and Management Sciences. 23(2). pp. 121-132.

TRANSINVEST KFT. (2015): Országos Kisvasúti Koncepció (OKK). Készült a Közeledésfejlesztési Koordinációs Központ megbízásából. Budapest. VLK CONSULTING KFT - DIGITAL SOLUTIONS KFT (2015): A kisvasutak szolgáltatás felmérése. Készült a Közlekedésfejlesztési Koordinációs Központ megbízásából. Budapest.

\section{Internetes források}

EUROPARC FEDERATION (2010): European charter for sustainable tourism in protected areas. https://www.europarc.org/library/europarcevents-and-programmes/european-charterfor-sustainable-tourism/, Letöltve: 2018. szeptember 26.

STRATÉGIA KONZORCIUM (2013): Nemzeti Közlekedési Stratégia - Országos Vasútfejlesztési Koncepció. Készült a Közlekedésfejlesztési Koordinációs Központ megbízásából. http:// www.kormany.hu/download/b/84/10000/Ne mzeti\%2520K\%25C3\%25B6zleked\%25C3\%25A 9si\%2520Infrastrukt\%25C3\%25BAra-fejleszt $\%$ 25C3\%25A9si\%2520Strat\%25C3\%25A9gia.pdf, Letöltve: 2018. szeptember 26. 